\section{IJ§ER}

ISSN: 2149-5939
International Journal of Social Sciences and Education Research

Online, http://dergipark.gov.tr/ijsser

Volume: 4(1), 2018

\title{
Domestic workers in Qatar
}

\author{
Nojoud Aldahri ${ }^{1}$ \\ Hessa Alsaqatri ${ }^{2}$ \\ Reem AlHadad ${ }^{3}$ \\ Ramah Almalouf ${ }^{4}$ \\ Fatma Kayan Fadlelmula ${ }^{5}$
}

Received Date: 05 / 09 / 2017

Accepted Date: 25 / $10 / 2017$

\begin{abstract}
This study examines domestic worker issue in Qatar, and aims to increase awareness on the negative aspects of non-parental childcare on children's growth. The findings shows that in Qatar many people have between 1 to 3 domestic workers. They find domestic workers to be highly important in their lives, but do not consider them trustworthy. Yet, many people give full responsibility of their house and chores to the workers, especially the responsibility of taking care of their children. Moreover, a high percentage of domestic workers are spending more time with children than their parents do, and children are losing touch with their mother language due to the non-parental care.
\end{abstract}

Keywords: Domestic Workers, Childcare, Civic Engagement, Qatar

\section{Introduction}

Nowadays the dependence on domestic workers has been tremendously increasing in the Gulf countries. According to the Migrant Rights Organization (2017), there are over 2 million domestic workers working in the Gulf region such that over 1.2 million in Saudi Arabia, +750 thousand in the United Arab Emirates, +620 thousand in Kuwait, and +400 thousand in Qatar. With the extensive number of domestic worker employment, domestic worker issue has become a regular part of mass media and the courts in the GCC countries witness a very high number of cases where domestic workers get physical or sexual abuse by their sponsors, work extensively, get unpaid, and have no contact with their families (Chalhoub, 2017; Wilson, 2016). Yet, with the partial exception of Bahrain, domestic workers are not included in the national labor laws and have no legal protection regarding their rights, working hours and safety conditions.

In addition to the issue of labor rights, domestic workers have also become the concern of several studies in the Gulf area, mostly pointing to the effect of non-parental childcare on the mental, physical and emotional development of children (Khalifa and Nasser, 2015). Many families in the region feel the need to hire domestic workers to do their house chores, look after their children and care for elderly family members. In particular, the vast majority of domestic workers come from India, Sri Lanka, Bangladesh, Philippines, Indonesia and Pakistan. They are often from the countryside either illiterate or semi-illiterate, having origins and traditions that differs from the families they work with (Roumani, 2005).

\footnotetext{
${ }^{1}$ Undergraduate student, Qatar University, Doha, Qatar, na1601507@student.qu.edu.qa

${ }^{2}$ Undergraduate student, Qatar University, Doha, Qatar, ha1610154@student.qu.edu.qa

${ }^{3}$ Undergraduate student, Qatar University, Doha, Qatar, ra1602192@student.qu.edu.qa

${ }^{4}$ Undergraduate student, Qatar University, Doha, Qatar, ra1601149@student.qu.edu.qa

${ }^{5}$ Dr., Core Curriculum Program, Qatar University, Doha, Qatar, fkayan@qu.edu.qa
} 
Aldahri, N., Alsaqatri, H., AlHadad, R., Almalouf, R., Kayan Fadlelmula, F. (2018). Domestic workers in Qatar. International Journal of Social Sciences and Education Research, 4(1), 32-40.

Studies show that children in their early ages tend to assimilate behaviors and attitudes they observe around them (Tembo, 2015). When parents do not spend enough time with their children and leave the responsibility of childcare to their housemaids, children often do not develop appropriate attitudes and behaviors. In this case, some children experience developmental difficulties and some suffer from psychological and speech problems as well (Sinaria, 2014). In this study, we explored domestic worker issue in Qatar, and aimed to increase awareness on the negative aspects of non-parental childcare on children's growth.

\section{Methodology}

Data were collected during the spring semester of 2016-2017 academic year, from 100 respondents. Quantitative techniques were used for data analysis. An online survey was developed by the researchers based on a detailed literature review. The survey was composed of five demographic questions and ten questionnaire items. Particularly, the demographic questions were related to participants' gender, age, nationality, the college they studied, and the number of domestic worker they had. The questionnaire items were written on a five-point Likert scale ranging from 1 (strongly disagree) to 5 (strongly agree).

Below is the list of the questionnaire items;

1. Having a house cleaner is important in life.

2. House cleaners are trustworthy.

3. House cleaner should have at least one day off.

4. House cleaner can have a cellphone.

5. House cleaners are treated decently in Qatar.

6. People give their house cleaners all their basic rights in Qatar.

7. House cleaners are given the full responsibility of house work and chores.

8. House cleaners are given the full responsibility of children.

9. House cleaners are spending more time with children than their parents do.

10. Children are losing touch with their mother language due to interaction with house cleaners.

\section{Results and discussion}

\subsection{Results of demographic information}

Participants responded to the demographic questions on their age, gender, nationalities, colleges, and the number of domestic workers they have in their house. Regarding the gender, the results showed that $80 \%$ of the participants were female and $20 \%$ were male. About age, most of the participants were young, aged between 17 to 20 years old (59\%), 21 to 24 years old (28\%), and 25 to 28 years old (2\%). Only 11 participants were older than 28 years (See Figure 1).

Considering the nationalities, non-Qatari participants (74\%) were a majority compared to Qataris $(26 \%)$. For the colleges, most of the participants were studying or graduated from the College of Arts and Science (38\%) and College of Engineering (23\%). 
Aldahri, N., Alsaqatri, H., AlHadad, R., Almalouf, R., Kayan Fadlelmula, F. (2018). Domestic workers in Qatar. International Journal of Social Sciences and Education Research, 4(1), 32-40.

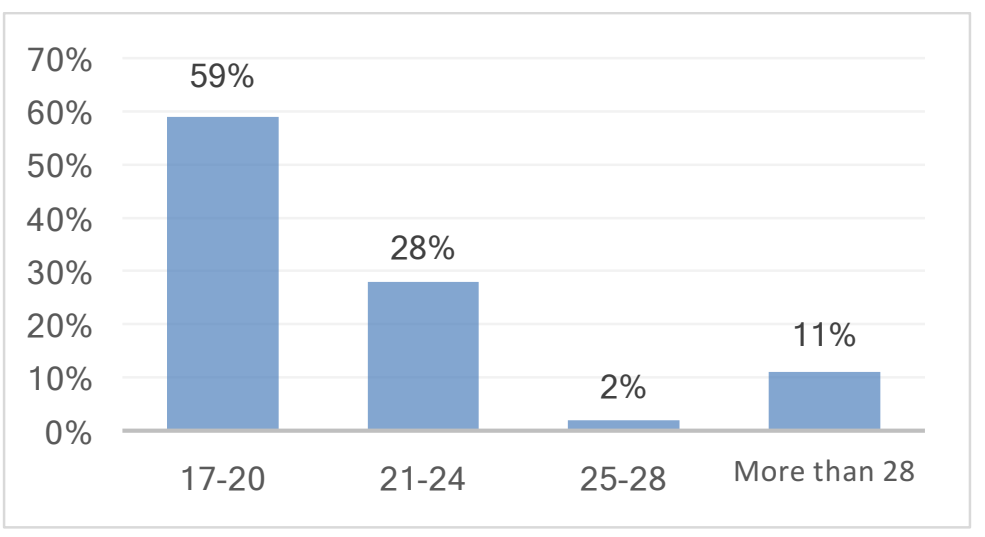

Figure 1. Age distribution

There were also participants from the College of Business and Economy (10\%), College of Health Science (9\%), College of Medicine (6\%), College of Education (5\%), College of Law (4\%), College of Sharia and Islamic Studies (3\%) and College of Pharmacy (2\%) (See Figure 2).

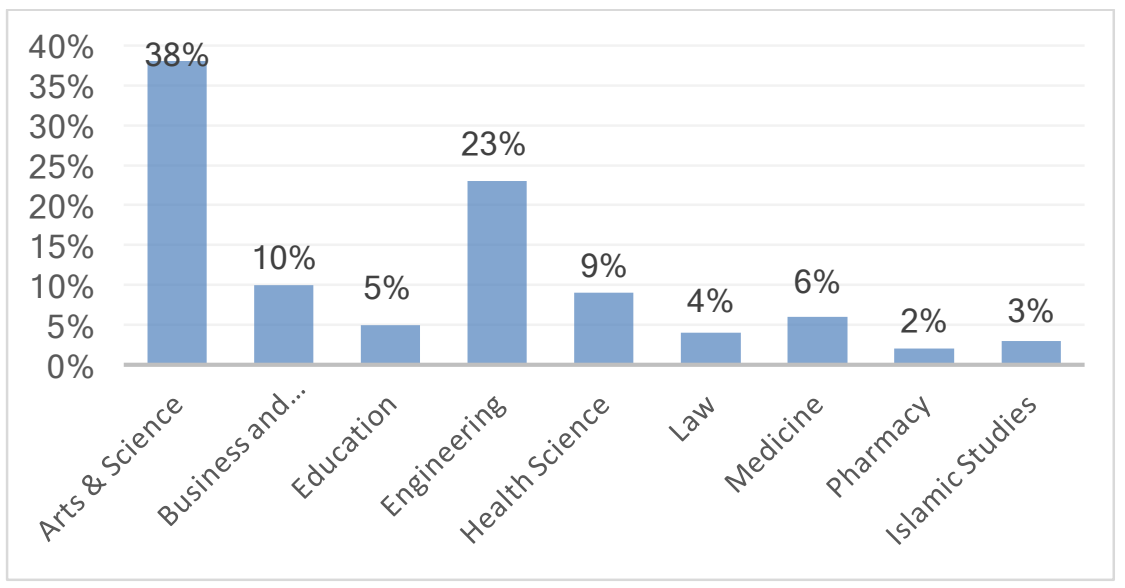

Figure 2. College distribution

Finally, regarding the number of house cleaners, majority of the participants (67\%) had 1 to 3 cleaners in their house. There were also a few participants with 4 to 6 cleaners $(6 \%)$ and even more than 6 cleaners (2\%). Only 25\% reported having no cleaner in their house (See Figure 3).

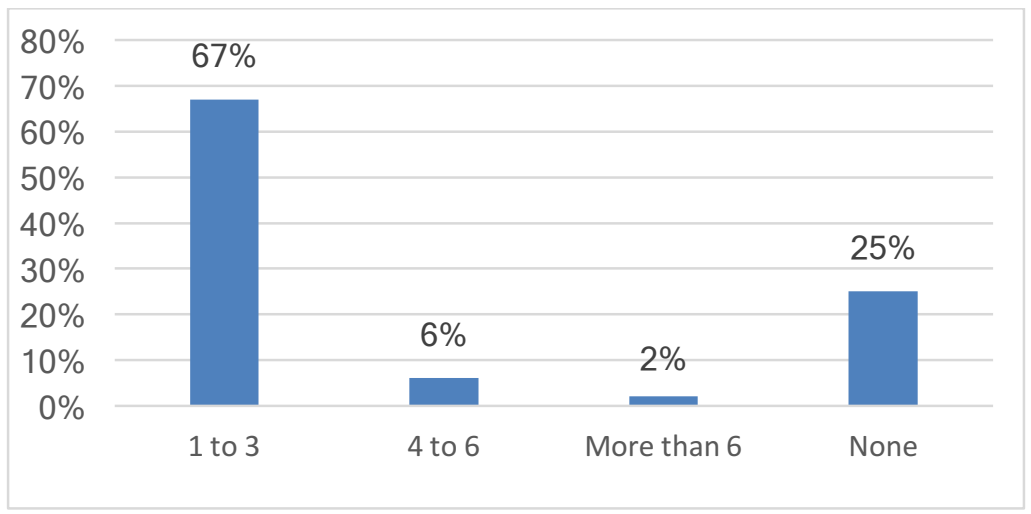

Figure 3. House cleaner distribution 
Aldahri, N., Alsaqatri, H., AlHadad, R., Almalouf, R., Kayan Fadlelmula, F. (2018). Domestic workers in Qatar. International Journal of Social Sciences and Education Research, 4(1), 32-40.

\subsection{Results of questionnaire items}

The survey contained ten questionnaire items on a five-point Likert scale. For the first item (Having a house cleaner is important in life), $36 \%$ of the participants indicated neither agreement nor disagreement. On the other hand, $30 \%$ of the participants reported agreement, $13 \%$ strong agreement, 18\% disagreement, and 3\% strong disagreement (See Figure 3). The results implied that only $21 \%$ of the participants did not consider having a house cleaner to be important in their lives.

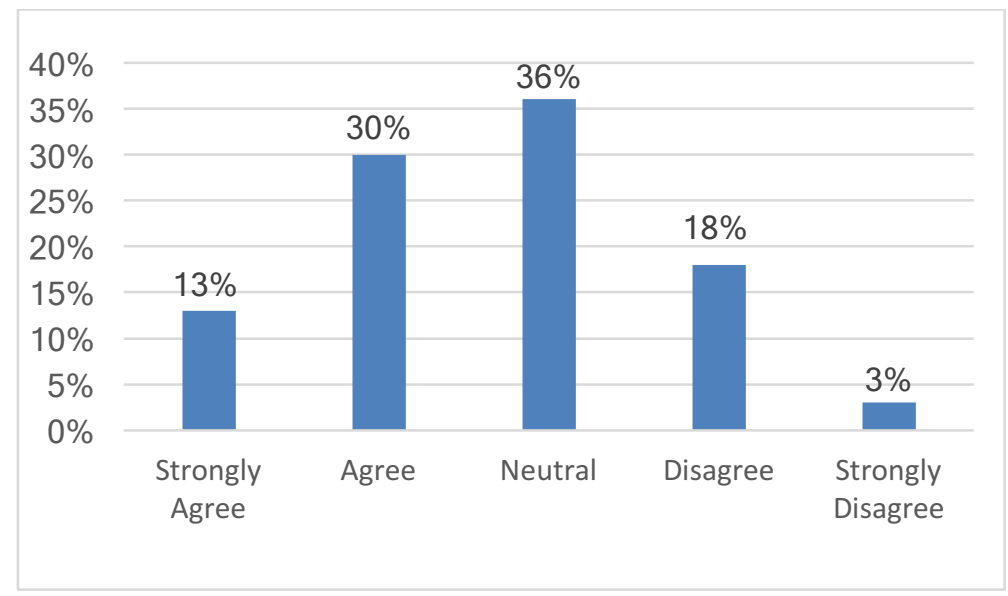

Figure 3. Having a house cleaner is important in life

For the second item (House cleaners are trustworthy), again the majority of the participants neither agreed nor disagreed (41\%). In addition, the total percentage of agreements $(23 \%$ agree and $5 \%$ strongly agree) was highly close to the total percentage of disagreements (27\% disagree and $4 \%$ strongly disagree) (See Figure 4 ).

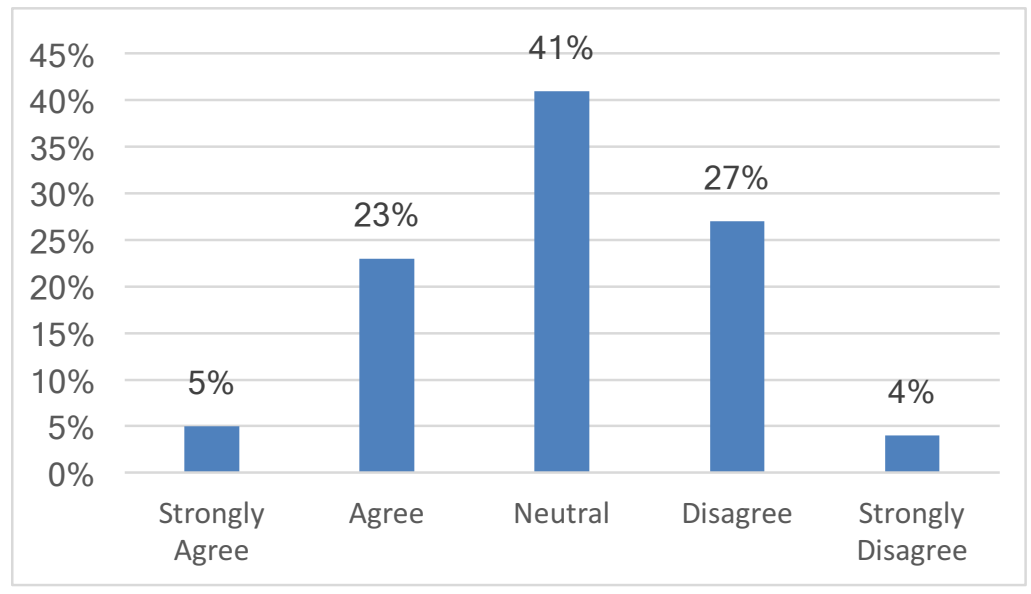

Figure 4. House cleaners are trustworthy

For the third item (House cleaners should have at least one day off.), almost all of the participants $(88 \%)$ either agreed (44\%) or strongly agreed (44\%) with the statement, whereas only $8 \%$ were neutral and $4 \%$ disagreed (See Figure 5). 
Aldahri, N., Alsaqatri, H., AlHadad, R., Almalouf, R., Kayan Fadlelmula, F. (2018). Domestic workers in Qatar. International Journal of Social Sciences and Education Research, 4(1), 32-40.

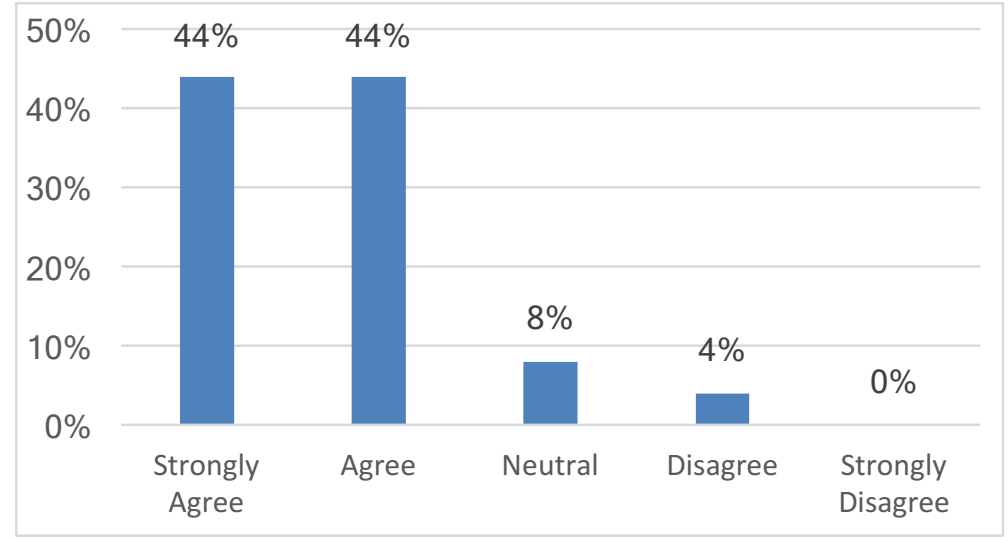

Figure 5. House cleaners should have at least one day off

For the fourth item (House cleaners can have a cellphone), again almost all of the participants $(85 \%)$ either agreed $(41 \%)$ or strongly agreed $(44 \%)$ with the statement, whereas only $8 \%$ were neutral, $6 \%$ disagreed, and 1\% strongly disagreed (See Figure 6).

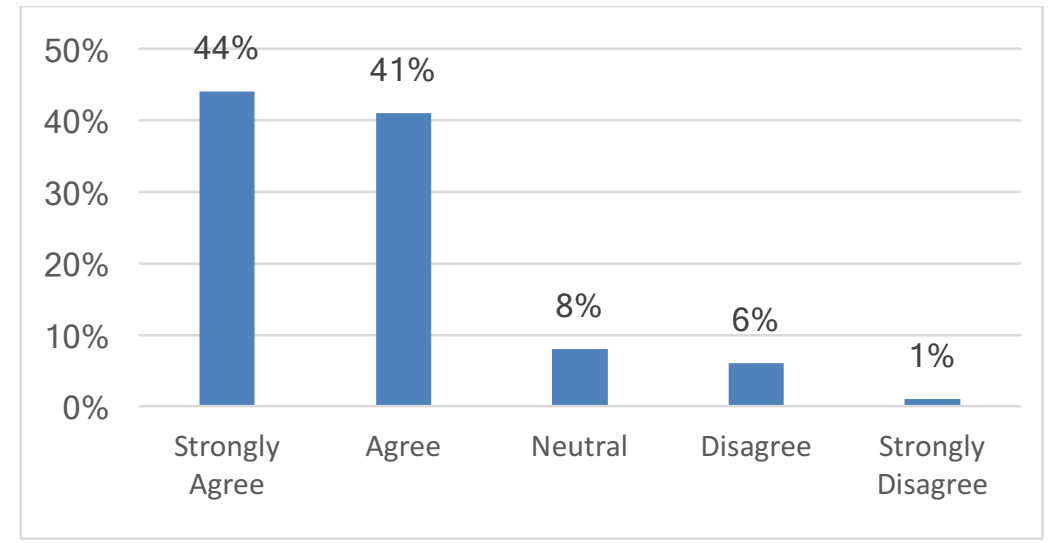

Figure 6. House cleaners can have a cellphone

For the fifth item (House cleaners are treated decently in Qatar), almost half of the participants were neutral, whereas $18 \%$ were in agreement (13\% agree and $5 \%$ strongly agree) and $33 \%$ were in disagreement (24\% disagree and 9\% strongly disagree) (See Figure 7).

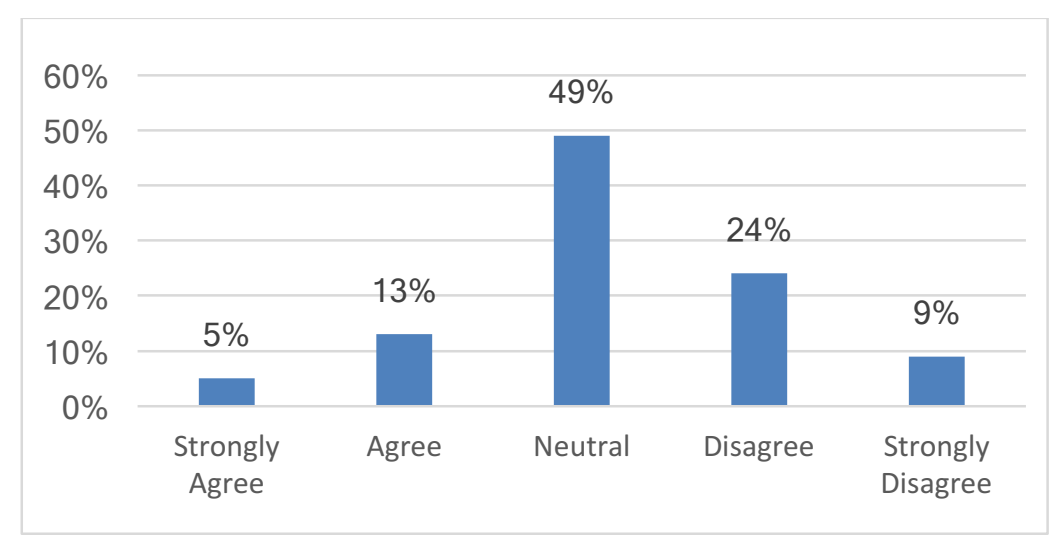

Figure 7. House cleaners are treated decently in Qatar 
Aldahri, N., Alsaqatri, H., AlHadad, R., Almalouf, R., Kayan Fadlelmula, F. (2018). Domestic workers in Qatar. International Journal of Social Sciences and Education Research, 4(1), 32-40.

For the sixth item (People give their house cleaners all their basic rights in Qatar), the majority of the participants neither agreed nor disagreed (38\%). On the other hand, the total percentage of agreements (18\% agree and 6\% strongly agree) was less than the total percentage of disagreements (29\% disagree and 9\% strongly disagree) (See Figure 8 ). The results implied that more participants believe that people do not give their house cleaners all their basic rights in Qatar.

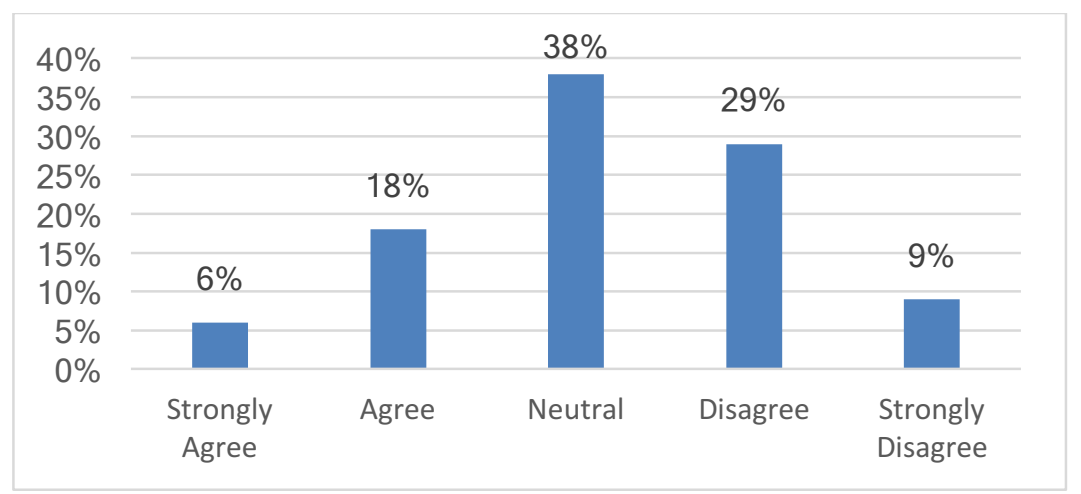

Figure 8. People give their house cleaners all their basic rights in Qatar

For the seventh item (House cleaners are given the full responsibility of house work and chores), the majority of the participants either agreed (46\%) or strongly agreed (21\%) with the statement, whereas $24 \%$ were neutral, $8 \%$ disagreed and only $1 \%$ strongly disagreed (Figure 9 ).

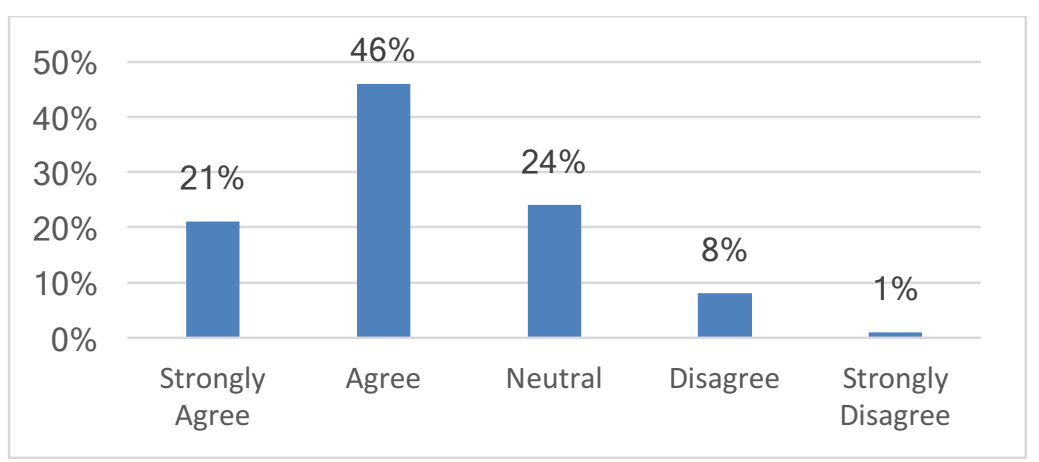

Figure 9. House cleaners are given the full responsibility of house work and chores

For the eight items (House cleaners are given the full responsibility of children), more than half of the participants were in agreement (36\% agree and $17 \%$ strongly agree), whereas $24 \%$ were neutral, $21 \%$ disagreed, and $2 \%$ strongly disagreed (Figure 10). The results revealed that only a few participants did not believe house cleaners are given the full responsibility of children in Qatar.

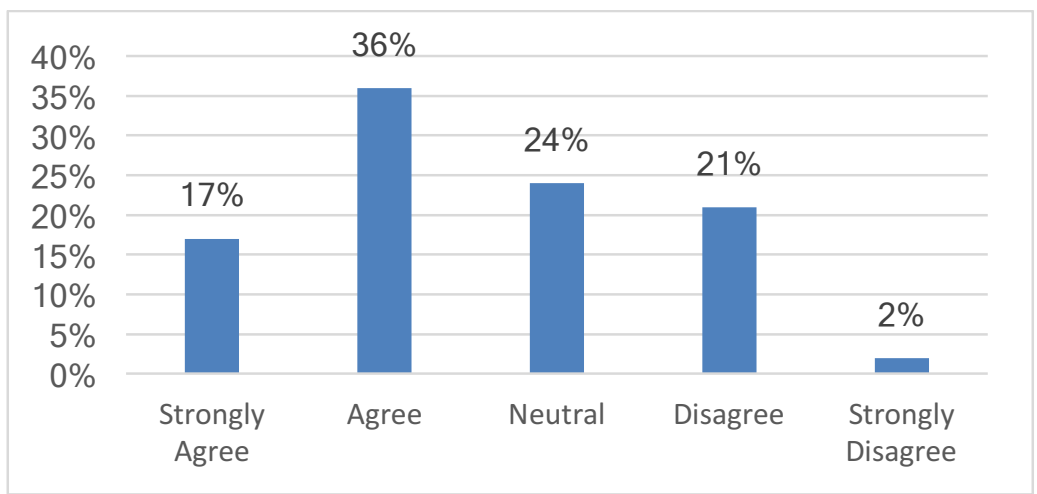

Figure 10. House cleaners are given the full responsibility of children 
Aldahri, N., Alsaqatri, H., AlHadad, R., Almalouf, R., Kayan Fadlelmula, F. (2018). Domestic workers in Qatar. International Journal of Social Sciences and Education Research, 4(1), 32-40.

For the ninth item (House cleaners are spending more time with children than their parents do), a high percentage of the participants either agreed (40\%) or strongly agreed (30\%) with the statement, whereas only a few were in disagreement ( $8 \%$ disagree and $4 \%$ strongly disagree) (See Figure 11). The results of Figure 11 support the results of previous figure, showing that in Qatar house cleaners are given the responsibility of childcare and they spend more time with children than their parents do.

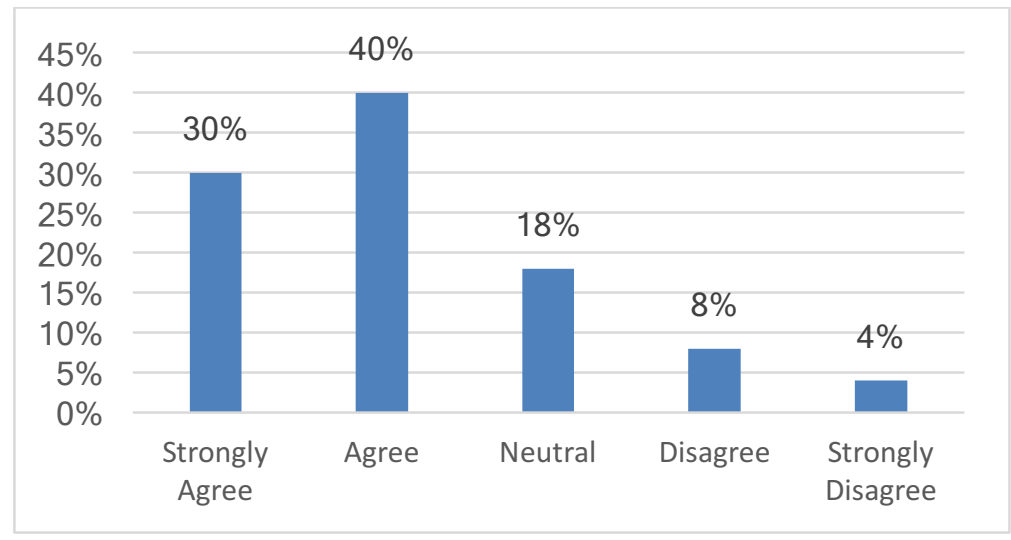

Figure 11. House cleaners are spending more time with children than their parents do

Finally, for the tenth item (Children are losing touch with their mother language due to interaction with house cleaners), very similar to previous findings, a high percentage of the participants either agreed $(33 \%)$ or strongly agreed $(26 \%)$ with the statement, whereas only a few were in disagreement (17\% disagree and 1\%strongly disagree) (See Figure 11). The results significantly support the idea that children spend more time with the house cleaners and due to the insufficient interaction with the parents they lose touch with their mother language.

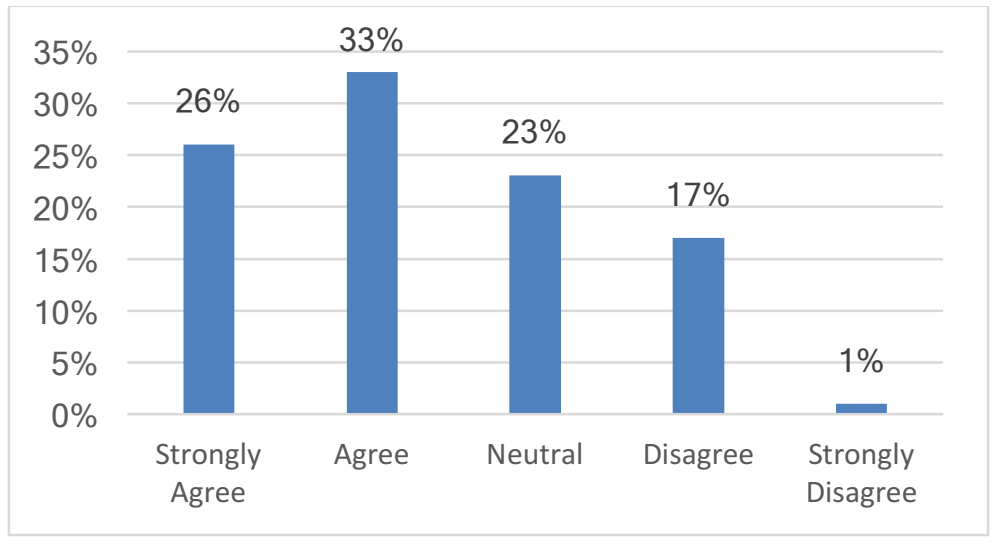

Figure 12. Children are losing touch with their mother language due to interaction with house cleaners

\section{Conclusion}

This study was performed for developing knowledge in domestic worker issue in Qatar. Data were collected during the spring semester of 2016-2017 academic year, from 100 respondents mostly female (80\%), Qatari (74\%), and aged between 17 to 20 (59\%). Participants completed an online survey, responding on a five-point Likert scale ranging from 1 (strongly disagree) to 5 (strongly agree). Quantitative techniques were used for data analysis. Briefly, the results revealed 
Aldahri, N., Alsaqatri, H., AlHadad, R., Almalouf, R., Kayan Fadlelmula, F. (2018). Domestic workers in Qatar. International Journal of Social Sciences and Education Research, 4(1), 32-40.

that most of the participants $(67 \%)$ had between 1 to 3 house cleaners, $6 \%$ had between 4 to 6 house cleaners, and $2 \%$ had more than six house cleaners in their house. In particular, almost half of the participants (43\%) reported that house cleaners are important to have in their lives, though $31 \%$ did not find them trustworthy. Only $18 \%$ of the participants agreed that domestic workers are being treated decently in Qatar, and simply $24 \%$ agreed that people give house cleaners all their basic rights in Qatar. On the other hand, majority reported that house cleaners can have a cell phone $(85 \%)$ and should have at least one day off each month. Furthermore, $67 \%$ of the participants believed that people are giving full responsibility of their house and chores to their house cleaners, especially the responsibility of taking care of children (53\%). Finally, participants agreed that house cleaners are spending more time with children than their parents do $(70 \%)$, and children are losing touch with their mother language due to the heavy exposure to the house cleaners (59\%).

There are many actions that can be taken to prevent or decrease the negative aspects of domestic worker issue. First, it is important to choose a trustworthy and healthy person that can intimately get familiar with your lifestyle, language, and culture. Then, once she gets into the house, she needs to be treated decently and considered as a part of the family. However, above all, families should keep in mind that the main responsibility of a domestic worker is to do the house chores such as cooking, cleaning and ironing. A house cleaner or a housekeeper should not become a replacement for parents. In this vein, previous studies clearly show that the environment in which children are brought up play an immense role in the development of children socially, psychologically and communally (Herbst, 2012; Khalifa and Nasser, 2015; Sinaria, 2014). Hence, it is recommended that parents keep being the locus of the family and take full responsibility of their childcare for developing own identity and building the social norms.

\section{References}

Aljawad, I. M. (1987). Impact of Asian Servants and Foreign Educators in the UAE (arabic book). Lebanon, Beirut

Aljawad, I. M. (1987). Impact of Asian Servants and Foreign Educators in the UAE (arabic book). Lebanon, Beirut.

Arslan, S., \& Özpınar, İ. (2008). Öğretmen Nitelikleri: İlköğretim Programlarının Beklentileri ve Eğitim Fakültelerinin Kazandırdıkları. Necatibey Eğitim Fakültesi Elektronik Fen ve Matematik Eğitimi Dergisi (EFMED), 2(1), 38-63.

Bozkuş, K., \& Marulcu, İ. (2016). Öğretmen Adaylarına Göre Etkili Öğretmen Nitelikleri. 8. Uluslararası Ĕgitim Araştırmaları. Çanakkale.

Gürbüzoğlu Yalmancı, S. (2016). Mikroöğretim Uygulamalarında Akran Değerlendirmelerini Etkileyen Niteliklerin Belirlenmesi. Kastamonu Eğitim Dergisi, 24(4), 2005-2020.

Gelbal, S., \& Kelecioğlu, H. (2007). Öğretmenlerin ölçme ve değerlendirme yöntemleri hakkındaki yeterlilik. Hacettepe Üniversitesi Eğitim Fakültesi Dergisi(33), 135-145.

Gençtürk, E., \& Sarpkaya, G. (2009). Sosyal Bilgiler Öğretmenlerinin Yeterlikleri. M. Safran içinde, Sosyal Bilgiler Öğretimi (s. 47-64). Ankara: Pegem Akademi.

Herbst, C. M. (2012, november ). The Impact of Non-Parental Child Care. http://ftp.iza.org/dp7039.pdf.

Khalifa, B. (2015, april). The Closeness of the Child to the Domestic Servant and its Mediation by Negative Parenting Behaiviors in an Arab Country. The journal of developing areas, https://www.aabss.org.au/system/files/published/000888-published-acbss-2015-sydney.pdf. 
Aldahri, N., Alsaqatri, H., AlHadad, R., Almalouf, R., Kayan Fadlelmula, F. (2018). Domestic workers in Qatar. International Journal of Social Sciences and Education Research, 4(1), 32-40.

Roumani, H. B. (2005). maids in Arabia. journal of early childhood research , http://www.gulfmontessori.com/Maids\%20in\%20Arabia\%20Journal.pdf.

Seferoğlu, S. S. (2004). Öğretmen adaylarinin öğretmen yeterlilikleri açisindan kendilerini değerlendirmeleri. Hacettepe Üniversitesi Ĕ̆itim Fakültesi Dergisi(26), 131-140.

Seferoğlu, S. S. (2004a). Öğretmen Yeterlilikleri ve Mesleki Gelişim. Bilim ve Aklın Aydınlı̆̆ında Ĕ̈itim(58), 40-45.

Sinaria, J. (2014, September). The Impact of Foreign Housemaids on the Children of Working Mothers. http://www.ingentaconnect.com/content/prin/ed/2014/00000135/00000001/art00007.

Şahin, A. (2004). Öğretmen Yeterliklerinin Belirlenmesi. Bilim ve Aklın Aydınlı̆̆ında Ĕ̆itim, 5(58), 58-62.

Tembo, T. (2015, April). Effects of Housemaids on Children. http://mwnation.com/effects-of-house-maidson-children/ 